会, p. 33 [講要].

Lambert, B., W. Theunis, R. Aguda, K.V. Audenhove, C. Decock, S. Jansens, J. Seurinck and M. Peferoen (1992 a) Gene 110: 131-132.

Lambert, B., H. Höfte, K. Annys, S. Jansens, P. Soetaert and M. Peferoen (1992 b) Appl. Environ. Microbiol. 58 :
$2536-2542$.

SeKar, V., D.V. Thompson, M.J. Maroney, M.R. Bookland and M.J. Adang (1987) Proc. Natl. Acad. Sci. USA 84: 7036-7040.

Sick, A., F. Gaertner and A. Wong (1990) Nucleic Acids Res. 18: 1305 .

\section{ナスノメイガの配偶行動と処女雌 トラップによる雄の誘引}

\author{
安田 慶次・川崎建次郎 ${ }^{1)}$ \\ 沖絈県農業試験場
}

Mating Behavior of Eggplant Fruit-Borer, Leucinodes orbonalis Guenée (Lepidoptera: Pyralidae) and Capture of Males in Virgin-Female Traps. Keiji Yasuda and Kenjirou KawASAKI ${ }^{2}$ (Okinawa Agricultural Experiment Station, Naha 903, Japan). Jpn. J. Appl. Entomol. Zool. 38: 302-304 (1994)

Abstract: The mating behavior of the eggplant fruit-borer was observed in the laboratory under natural light conditions. Copulation occurred around 04:40 and the duration was 73 minutes. Virgin-female traps captured males both in a large-field cage, and in an eggplant field. Males were trapped between $04: 00$ and 05:00 in the field. This result coincided with the time of copulation observed in the laboratory.

Key words: eggplant fruit borer, mating behavior, sexattractant trap

ナスノメイガ Leucinodes orbonalis GUENNE は東南アジア，ア フリカに広く分布するナスの害虫である(高良・東, 1969)。日 本では 1964 年に沖縄県那覇市で発見されて以来, 全県下に分布 を拡大した（玉城・宮良，1982）。1980 年後半より沖縄本島で は被害はほとんど認められなくなったが，宮古島，石垣島では 依然重要な害虫である (安田・桃木, 1988)。本種の幼虫は寄主 植物の果実および茎の内部に食入するため, 被害の発見が遅れ ることが多い。そのため，本種の性フェロモンを発生調査に利 用することは有用と考它られ，トラップおよび合成性フェロモ ンの開発が必要となっている。そこで本種のフェロモントラッ プの開発に必要な知見を得るため, 飛翔行動, 交尾行動, 交尾 時刻，交尾継続時間，雌成虫による雄成虫の誘引についての調 査を行ったので，その結果を報告する。
なお，本研究を進めるにあたり，多くの御助言を頂いた沖縄 県農業試験場玉城信弘研究主幹, 宮竹貴久研究員および農林水 産省農業環境技術研究所山村光司博士に感謝する。

\section{材 料と方 法}

供試虫は野外から採集後, $27^{\circ} \mathrm{C}, 12 \mathrm{~L}-12 \mathrm{D}$ (点灯午前 6 時) の条件でナスの果実で 3 世代飼育したものを用いた。蛹化した 蛹は腹部の形態の違いにより雌雄を分け, 別々の直径 $8 \mathrm{~cm}$ 高 さ $4 \mathrm{~cm}$ の円筒形透明スチロール容器に入れた。羽化は玉城・ 宮良 (1982) および事前の観察により夜間のみに行われることが 明らかであったので, 調査前日の午前 10 時より当日の午前 10 時までに羽化したものをその日の羽化成虫 (1 日龄) とした。成 虫は雌雄別々に上記と同様な容器に保管し, 観察日まで餌とし て水で 2 倍に薄めたハチミッと水をそれぞれ脱脂綿に浸ませて 与えた。

上記の容器に 1 日齢の 1 対の雌雄成虫拉よび上記と同様の慨 と水を入れ，合計 52 対の成虫について観察を行った。調査は沖 縄県那覇市で, 1991 年 9 月 3 日と 4 日に行い, 両日とも日の 出が 6 時 10 分, 日の入りが 18 時 48 分であった。調査中の室 温はほぼ $28^{\circ} \mathrm{C}$ に保たれた。容器は空際に置き，正午より 24 時 間，はばたきと飛翔，および交尾の有無について連続的に観察 を行った。交尾は雌雄の交尾器を結合させたものとし，交尾開 始時刻および継続時間を調べた。夜間の観察は舞台照明用の赤 色ゼラチンを前面に付けた懐中電灯の照明下で行った。

処女雌トラップヘの誘引試験は野外網室と本種の発生が認め られた露地ナス畑で行った。なお，雄成虫を誘引源とする試験 は事前の調査で雌雄ともに誘引が認められなかったので行わな かった。調査に用いた網室は $3 \mathrm{~m} \times 2 \mathrm{~m} \times$ 高さ $1.8 \mathrm{~m}$ で，その 中へ 6 個の武田式粘着トラップ®，を直径 $1.2 \mathrm{~m}$ の同心円上に $30 \mathrm{~cm}$ の高さで設置した。誘引源として 1 日龄の処女雌 5 頭を 餌の 10 倍に薄めたハチミッを浸ませた脱脂綿と共にステンレス 製網張りの直径 $5 \mathrm{~cm}$ の半球形の容器に入れ, その容器をトラ ップ内へ一つ置きに合計 3 個置き，残りのトラップには慨の八

1) 現在 亘系昆虫農業技術研究所

2) Present address: National Institute of Sericultural and Entomological Science, Tsukuba, Ibaraki 305, Japan.

日本応用動物昆虫学会誌 (応動昆) 第 38 巻 第 4 号 : 302-304 (1994)

1994 年 3 月 3 日受領 (Received 3 March 1994)

1994 年 5 月 28 日登載決定 (Accepted 28 May 1994) 
チミツの入った容器のみを入れ対照とした。実験は1991年 9 月

7 日より 10 月 11 日の間に 5 回行った。 9 月 7 日から 9 月 10 日までの日の出時刻は 6 時 11 分から 13 分の間で, 日の入りが 18 時 44 分から 41 分の間で, 平均気温は $28.7^{\circ} \mathrm{C}$ より $29.7^{\circ} \mathrm{C}$ の間を示した。 10 月 8 日は日の出が 6 時 25 分日の入りが 18 時 18 分で, 平均気温が $26.2^{\circ} \mathrm{C}$ であった。網室へ放飼した雄成 虫は未交尾の 1 日跲から 2 日跲のものを用いた。放飼虫数は 9 月 7 日が 100 頭， 9 月 8 日が 15 頭，9月 10 日が 34 頭， 9 月 14 日が 45 頭, 10 月 8 日が 50 頭であった。放飼は午後 3 時に 行い, 翌日の午前 9 時にトラップに捕獲された虫数の調査と網 室内の虫の回収を行った。

野外での誘引試験は 1991 年 9 月 12 日から 9 月 14 日にかけ て 2 晚, 宮古島平良市の $1,200 \mathrm{~m}^{2}$ のナス畑で行った。ナス畑 には網室での試験と同型のトラップ 10 個を畑の風上側に風向と 直角に $4 \mathrm{~m}$ 間隔で固いた。一つ置きに 5 個のトラップには調査 日ごとに網室試験と同様に 1 日齢の処女雌 5 頭の入った容器を 貣き，残りの 5 個のトラップは対照区とした。誘引時刻を調べ るために 15 時に処女脽の入った容器をトラップ内に置き, 16 時より翌朝の 8 時まで 1 時間おきに捕殺虫数を調べた。なお， 事前の調査でハチミッの入った容器へは誘引されなかったので, 対照区のトラップへは容器は置かなかった。

結果 と考 察

\section{1. 室内観察}

容器内での行動として, 静止, 停止状態でのはばたきと飛翔,

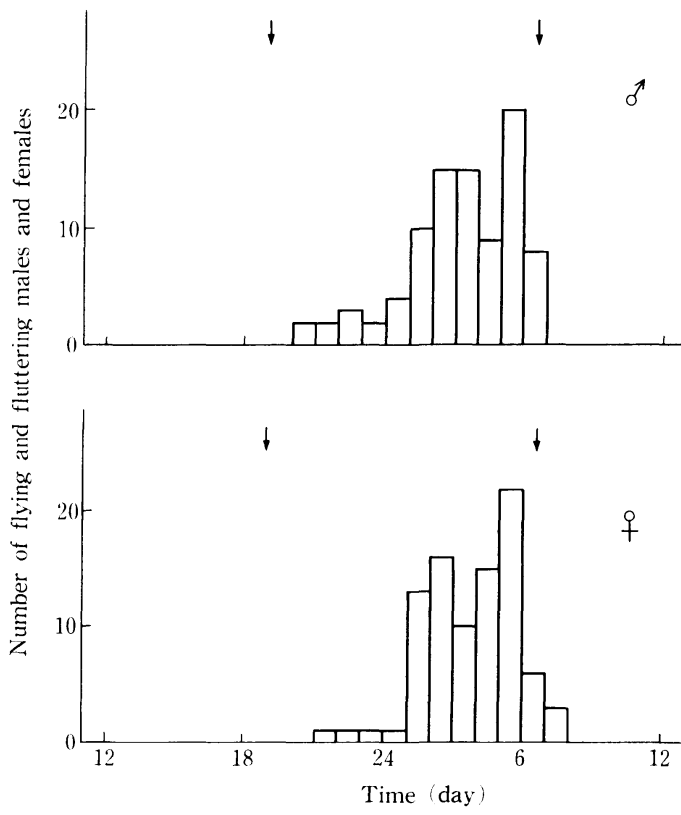

Fig. 1. Time of flying and fluttering of Leucinodes orbonalis. Arrows indicate sunrise and sunset.
歩行および交尾が認められた。はばたきと飛翔は連続して起こ る事が多いため，第 1 図は両者を合わせて示した。はばたきと 飛翔行動は雌雄共に日没 1 時間後より認められ，その後次第に 増加し，後夜半にピークを作り，日の出後に激減する 1 山型を 示した (Fig. 1)。

交尾は 2 日齢の 52 対中 16 例観察された (Fig. 2)。平均交 尾開始時刻は午前 4 時 36 分で，交尾継続時間は最長が 1 時間 51 分, 最短が 12 分, 平均が 1 時間 13 分であった。交尾の観 察される時刻になると雌成虫は通常静止状態では背面にそり返 らせ動かさないでいる腹部を上下に動かし，羽を細かく震わせ るのが観察された。雄成虫ははばたきながら歩行で雌成虫の側 面に近づき，腹部先端を主として左右に動かしながら，交尾器 を雌の側に向け結合させた。さらに，腹部先端を結合させたま ま頭部が互いに反対側を向くような姿勢をとって静止し，交尾 を続けた。また，夜明け直前に交尾した 5 対については日の出 後もそのまま交尾が続いた。なお，1 日齢の雌雄成虫 28 対では 交尾は認められなかった。

\section{2. 網室での誘引試験}

網室でのトラップへの誘引雄成虫数は 5 回の実験すべてにお いて処女踓トラップが対照のトラップを上回った (Table 1)。5 回の調査で処女雌トラップの総捕殺虫数は 33 頭に対し対照のト ラップはわずか 2 頭で，二項分布に基づく正確な確率検定によ りその差は有意であった $(p<0.01)$ 。なお，対照のトラップに捕 般された 2 頭は偶然にトラップに飛び込んだものと考えられた。

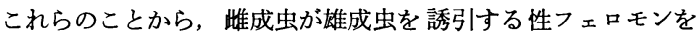
放出していることが示唆された。

\section{3. 野外围場での誘引試験}

野外での誘引試験では，2 晚で合計 15 頭の雄成虫が処女雃ト

Table 1. Catches of male L. orbonalis in virgin-females traps in large cage

\begin{tabular}{cccc}
\hline Date & $\begin{array}{c}\text { No. of males } \\
\text { released }\end{array}$ & \multicolumn{2}{c}{ No. of males caught } \\
\cline { 3 - 4 } & & $\begin{array}{c}\text { virgin-female } \\
\text { traps }\end{array}$ & $\begin{array}{c}\text { control } \\
\text { traps }\end{array}$ \\
\hline $7-8$ Sep. & 100 & 14 & 0 \\
8-9 Sep. & 14 & 2 & 0 \\
10-11 Sep. & 34 & 2 & 1 \\
14-15 Sep. & 45 & 7 & 0 \\
8-9 Oct. & 50 & 8 & 1 \\
\hline Total & 244 & $33^{\mathrm{a}}$ & 2 \\
\hline
\end{tabular}

a Significantly different at $1 \%$ level.

Table 2. Catches of male $L$. orbonalis in virgin-female traps in eggplant field

\begin{tabular}{lccc}
\hline & $12-13$ Sep. & $13-14$ Sep. & Total \\
\hline Virgin female traps & 5 & 10 & $15^{\mathrm{a}}$ \\
Control traps & 0 & 0 & 0 \\
\hline
\end{tabular}

a Significantly different at $1 \%$ level. 


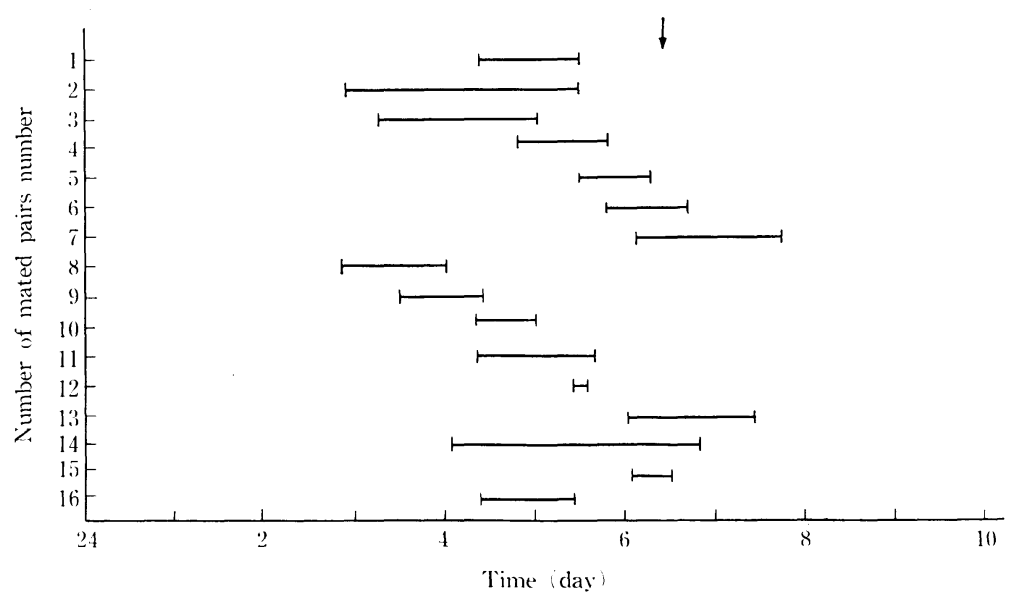

Fig. 2. Duration of copulation of $L$. orbonalis. Arrows indicate sunrise.

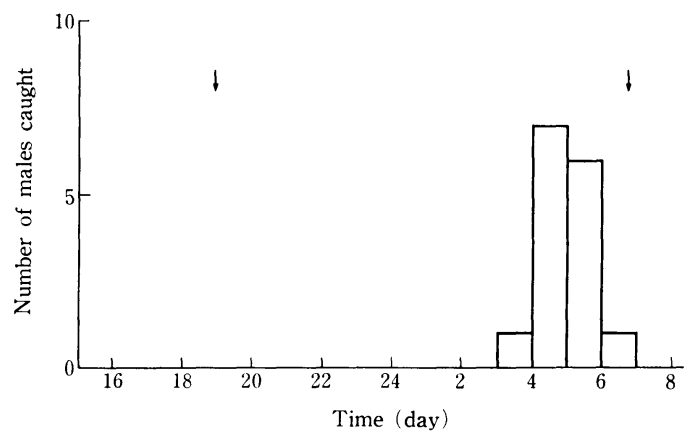

Fig. 3. Capture time of male $L$. orbonalis in virgin-female traps. Arrows indicate sunrise and sunset.

ラップで捕殺されたが (Table 2)，対照のトラップでの捕殺は 認められず，その差は二項分布に基づく正確な確率検定により 有意であった $(p<0.01)$ 。成虫の飛翔は日没直後よりナス畑で観
察されたが，前夜半に捕殺されたものはなく，Fig. 3 に示した ように午前 4 時〜 5 時に捕殺のピークが認められた。なお, 固 場が明るくなってからは全く捕殺されなかった。

以上の結果ナスノメイガの 飛翔行動は日没後始まり，室内で は午前 1 時頃より多くの飛翔が観察され, 交尾は午前 2 時より 6 時の間に起こり，ピークは午前 5 時頃であった。交尾開始時 刻は平均 4 時 36 分で野外に括ける処女雌に対する雄成虫の捕 殺ピーク時刻とほぼ一致したことから，倠成虫のフェロモンの 放出時刻は日没約 10 時間後, 午前 4 時頃を中心に午前 2 時よ り午前 6 時の間の後夜半と推察された。

$$
\text { 引用文 献 }
$$

高良鉄夫・東 清二 (1969) 沖縄農業 8: 31-32.

玉城信弘・宮良安正 (1982) 九病虫研会報 28: 158-162.

安田慶次 - 桃木徳博 (1988) 九病虫研会報 34: 139-140. 